\title{
Analytical Decline Curve Analysis Model for Water Drive Gas Reservoirs
}

Mostafa S Abdelkhalek ${ }^{1 *}$, Ahmed H El-Banbi ${ }^{2}$ and Mohamed H Sayyouh ${ }^{3}$

${ }^{1}$ Reservoir Engineer, Royal Dutch Shell, Egypt

${ }^{2}$ Cairo University/AUC, Egypt

${ }^{3}$ Cairo University, Egypt

\begin{abstract}
Production data analysis is a viable tool for reservoir characterization and estimation of initial gas in place (IGIP) and reserves. Several methods are available to analyse production data starting with Arps classical decline curve analysis (DCA) in 1945 all the way to more sophisticated analytical and advanced DCA techniques. Most of these methods are applicable only for single phase flow in porous media. In this paper, we present a simple analytical decline curve analysis (ADCA) model that takes into account the effect of water influx on gas reservoir performance. We introduced the water influx effect into the pseudo-steady state flow equation which enables us to estimate the reservoir pressure and the IGIP for water drive gas reservoirs. The model is based on coupling the material balance equation for gas reservoirs, aquifer models, and the gas flow equation to calculate the well's production rate versus time. The model can also estimate reservoir pressure, gas saturation, water production rate, and gas production rate with time.

When the model is run in history-match mode to match gas and water production, we can estimate the IGIP, well's productivity index, and aquifer parameters. The model can also be run in prediction mode to predict gas and water production at any conditions of bottom-hole flowing pressure (BHFP) (or surface tubing pressure) and reserves can be calculated. The model was validated with several simulated cases at variable conditions of rate and pressure. The model was then used to perform decline curve analysis in several field cases. This technique is fast and requires minimum input data. The paper will also present the application of this technique to analyse production data and predict reserves for gas wells producing both gas and water.
\end{abstract}

Keywords: Analytical model; Decline curve analysis; Water drive reservoirs; Multi-phase flow

Nomenclature: ADCA: Analytical decline curve analysis; Bgi: Initial gas formation volume factor, bbl/scf; BHFP: Bottom hole flowing pressure, psia; Bw: Water formation volume factor, bbl/stb; C: Gas flow coefficient, scf/psia2; Ce: Effective isothermal compressibility factor, psi1; DCA: Decline curve analysis; ew: Water influx rate, bbl/day; G: Initial gas in place, scf; h: Net pay thickness, ft; IGIP: Initial gas in place, scf; k: Permeability, mD; kgr: Gas relative permeability; kwr: Water relative permeability; $\mathrm{m}(\mathrm{p})$ : Real gas pseudo pressure, psia2/cp; $\mathrm{m}(\mathrm{pi})$ : Real gas pseudo pressure at initial reservoir pressure, $\mathrm{psia} 2 / \mathrm{cp} ; \mathrm{m}(\mathrm{pwf})$ : Real gas pseudo pressure at BHFP, psia2/cp; MBE: Material balance equation; $n$ : Gas flow exponent; NRS: Numerical Reservoir Simulation; p: Pressure, psia; PDHG: Permanent down hole gauge; pr: Reservoir pressure, psia; psc: standard pressure, psia; pwf: Bottom hole flowing pressure, psia; QA: Quality Assurance; QC: Quality Control; qw: Water production rate, bbl/day; Qg: Gas production rate at standard conditions, scf/day; Qw: Water production rate at standard conditions, stb/day; re: Drainage radius, ft; rw: Wellbore radius, ft; rwa: Apparent wellbore radius, ft; $\mathrm{S}$ : Skin factor; T: Temperature, ${ }^{\circ} \mathrm{R}$; Tsc: Standard temperature, ${ }^{\circ} \mathrm{R}$; Z: Gas deviation factor; $\mu \mathrm{g}$ : Gas viscosity, cp; $\mu \mathrm{w}$ : Water viscosity, $\mathrm{cp}$

\section{Introduction}

Several methods are available to analyse reservoir performance which can be used to estimate IGIP, gas production rate, water production rate, gas saturation, and reservoir pressure.

These methods can be classified into three categories:

a. Classical material balance [1-3]

b. Numerical reservoir simulation $[4,5]$.

c. Dynamic production data analysis [6].

Classical material balance can mainly be used to estimate IGIP and identify the reservoir drive mechanism. One of the main inputs for this method is the static reservoir pressure on regular basis. Static reservoir pressure measurement requires wells' shut-in and running a pressure gauge in the well or installation of permanent down-hole pressure gauge (PDHG) to measure the static pressure when the well is shut-in for long time. Shut-in production wells for a static pressure measurement is not always justifiable which might impose a constraint on applying this method. Using classical material balance to predict wells' performance requires the estimation of IPR at different static reservoir pressure. More importantly, it requires estimation of watergas ratio at future reservoir pressure, which is not easily available.

Numerical reservoir simulation can also be used to analyse reservoir performance, but it requires large amounts of data and it can be time consuming to build the static and dynamic models. The model has also to be validated and history-matched against actual production and pressure data which may not be available sometimes (e.g. case of little or no production history of the field).

Dynamic production data analysis is another approach to analyse and estimate reservoir performance. Among the most important approaches in decline curve analysis is:

a. Arps Decline Curve Analysis (DCA).

Corresponding author: Mostafa S. Abdelkhalek, Reservoir Engineer Royal Dutch Shell, Cairo University, Egypt, Tel: +201112410025; E-mail: mostafa_sayed_eng@yahoo.com

Received June 01, 2017; Accepted October 12, 2017; Published October 16 2017

Citation: Abdelkhalek MS, El-Banbi AH, Sayyouh MH (2017) Analytical Decline Curve Analysis Model for Water Drive Gas Reservoirs. J Pet Environ Biotechnol 8: 343. doi: 10.4172/2157-7463.1000343

Copyright: (C) 2017 Abdelkhalek MS, et al. This is an open-access article distributed under the terms of the Creative Commons Attribution License, which permits unrestricted use, distribution, and reproduction in any medium, provided the original author and source are credited. 


\section{b. Fetkovich type curve.}

c. Blasingame type curve.

\section{d. Agarwal-Gardner type curve.}

e. Flowing material balance.

The production data analysis methods started long ago when a decline trend was used as a tool for economic evaluation. Arps in 1945 presented the classical decline curve analysis (DCA) technique which is based on pure empirical observation.

Arps [7] DCA can be used to estimate the reserves for declining production well. It cannot be used to estimate the IGIP nor dynamic performance data; such as, reservoir pressure, gas saturation, water production rate, etc. Arps DCA cannot be used also for what-if scenarios (e.g. production against different bottom-hole flowing pressure).

In 1980s Fetkovich [8] presented his type curve analysis technique that combined the unsteady state flow solution and Arps DCA for the pseudo steady state flow. He used the equations from the pressure transient analysis to represent the unsteady state flow period and combined it with Arps equations to represent the pseudo steady state flow period. Fetkovich type curve technique cannot be utilized unless production is under constant BHFP.

In 1990s Blasingame [9-11] presented another type curve analysis technique that overcomes the limitations of Fetkovich type curve. Blasingame introduced the idea of material balance time which can be used for variable rate and variable BHFP cases. Using the material balance time eliminates the assumption of production under constant BHFP which was the basis for Fetkovich type curve.

Agarwal and Gardner [12] also presented a method to estimate the IGIP. They suggested plotting the dimensionless flow rate versus the dimensionless cumulative production on a Cartesian scale. The result will be a straight line with the $\mathrm{X}$-axis intercept giving the IGIP.

Flowing material balance [13-16] is another technique used to estimate the IGIP without the need to shut the well in for static reservoir pressure measurement. It uses the BHFP along with the production rate in the pseudo steady state flow period to estimate the IGIP.

Most dynamic production data analysis can only be applied when there is a single-phase flow in the reservoir. In other words, dynamic production data analysis techniques cannot be applied for water drive reservoirs. This limitation arises because most of these methods are based on single fluid flow equation which does not account for water flow inside the reservoir.

\section{Model Description and Approach}

The ADCA model is based on coupling the material balance equation, an aquifer model, and flow equation for gas and water. The model uses an iterative procedure. The model consists of two nested iterative loops. The inner loop is used to estimate the reservoir pressure and water influx rate as functions of time while the outer loop is used to calculate the IGIP.

Once the IGIP, reservoir pressure, and water influx rate are calculated from the iterative procedure; the model can be used to do multiphase flow calculations for history-matching both gas production rate and water production rate. The developed model has the capability to be run with any of the analytical water influx models. Total of 13 analytical water influx models have been integrated into the ADCA model. The 13 water influx models represent different degree of pressure maintenance, outer boundary condition, flow regimes, and flow geometries. It gives the user a great flexibility to find out the appropriate aquifer model that best suits his/her reservoir-aquifer system.

After the history-matching process is complete, a number of prediction runs can also be performed at different BHFP scenarios. The outputs of prediction runs are future reservoir pressure, gas production rate, water production rate, and gas saturation; all as functions of time. Figure 1 shows the ADCA model methodology

\section{Initial gas in place estimation}

The model is based on the analytical solution of partial differential equation that describes the fluid flow in the reservoir as a function of time and space. Therefore, the pseudo steady-state flow equation has been adjusted to take into consideration the effect of water influx in case of water-drive gas reservoirs.

The following six equations have been combined together to create the analytical decline curve analysis model:

a. Conservation of mass.

b. Darcy's law.

c. Equation of state.

d. Boundary and initial conditions.

e. Water influx.

f. Estimate of relative permeability.

Eq. 1 is considered to be the cornerstone equation of the ADCA model

$$
\begin{aligned}
& \frac{\mu Z\left[m\left(p_{i}\right)-m\left(p_{w f}\right)\right]}{5.615 p\left[\left(\frac{p_{s c}}{T_{s c}} \frac{Z T}{p} \frac{Q_{g}}{5.615}\right)-e_{w}+q_{w}\right]} \\
& =\frac{2}{C_{e} G B_{g i}} t+\frac{\mu}{0.00083 k h}\left[\operatorname{Ln}\left(\frac{r_{e}}{r_{w a}}\right)-0.75\right]
\end{aligned}
$$

Eq.1 reveals that there are three unknowns in that equation that require an iterative routine to solve it. The three unknowns are IGIP, reservoir pressure, and water influx rate. Eq.1 shows that a plot of the left-hand side versus material balance time on a Cartesian scale would yield a straight line. The slope of the straight line can be used to estimate the initial gas in place.

\section{Multiphase flow calculations for gas and water production}

After estimation of the reservoir pressure and water influx rate, the production rate of gas and water can be calculated using the Darcy's multiphase flow equation as given in Eq. 2 and Eq. 3 for gas and water respectively.

$$
\begin{aligned}
& \mathrm{Q}_{\mathrm{g}}=\frac{(\mathrm{kh}) \mathrm{k}_{\mathrm{gr}}\left[\mathrm{m}\left(\mathrm{p}_{\mathrm{r}}\right)-\mathrm{m}\left(\mathrm{p}_{\mathrm{wf}}\right)\right]}{1.42 \mathrm{~T}\left[\ln \left(\mathrm{r}_{\mathrm{e}} / \mathrm{r}_{\mathrm{w}}\right)-0.75+\mathrm{s}\right]} \\
& \mathrm{Q}_{\mathrm{w}}=\frac{0.00708(\mathrm{kh}) \mathrm{k}_{\mathrm{wr}}\left[\mathrm{p}_{\mathrm{r}}-\mathrm{p}_{\mathrm{wf}}\right]}{\mathrm{B}_{\mathrm{w}} \mu_{\mathrm{w}}\left[\ln \left(\mathrm{r}_{\mathrm{e}} / \mathrm{r}_{\mathrm{w}}\right)-0.75+\mathrm{s}\right]}
\end{aligned}
$$

The real gas pseudo pressure used for gas production rate calculation is given in Eq. 4

$$
\mathrm{m}(\mathrm{p})=\int_{0}^{\mathrm{p}} \frac{2 \mathrm{p}}{\mu_{\mathrm{g}} \mathrm{z}} \mathrm{dp}
$$

If the model is run in the history-match mode, the estimated 


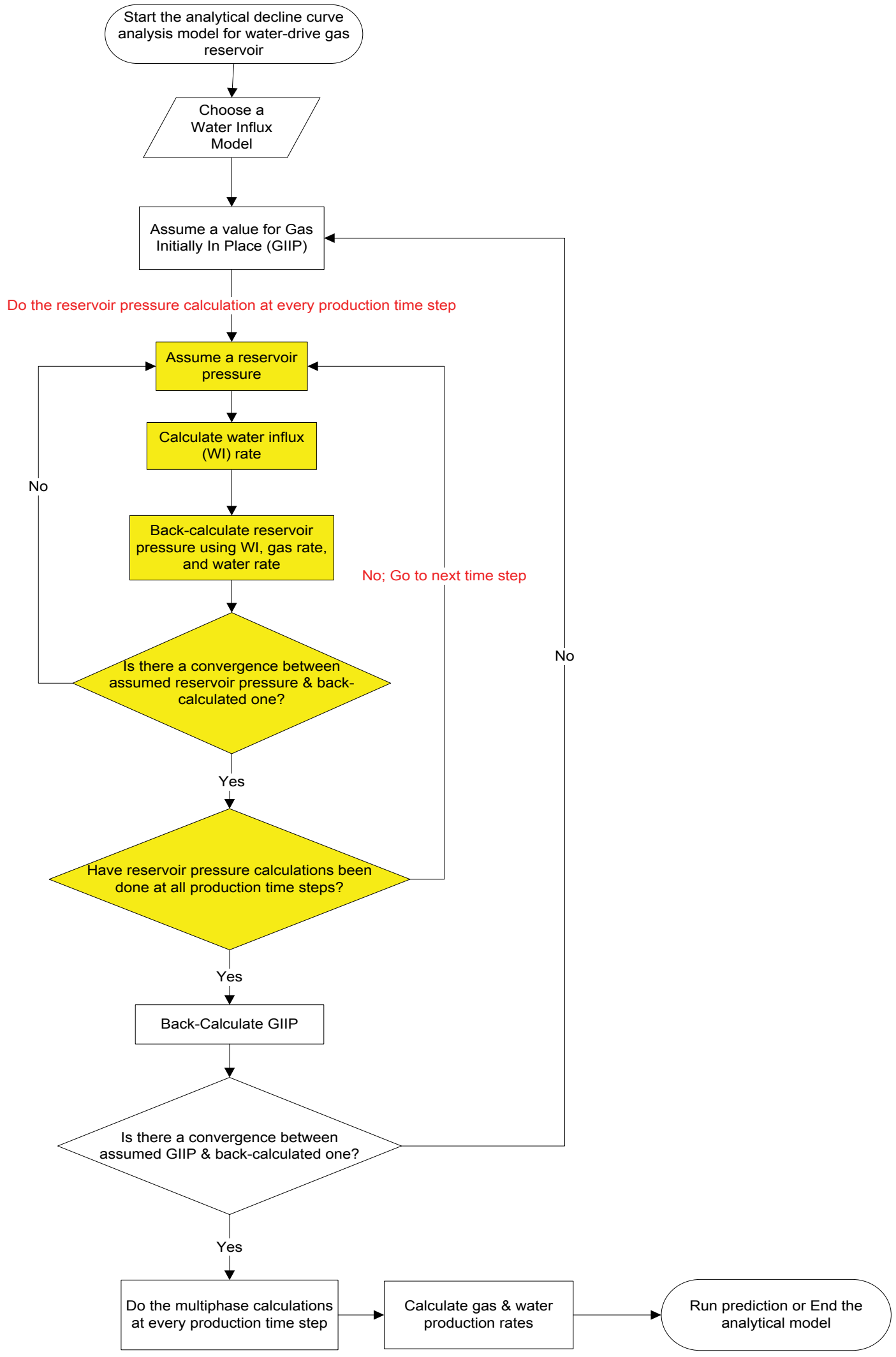

Figure 1: Analytical decline curve analysis model methodology. 
gas and water rates will be compared with the actual rates and new estimates for IGIP, aquifer model parameters, and well's $k h$ and skin will be assumed using an optimization routine.

\section{Input data}

To run the analytical decline curve analysis model, the following data will be needed:

a. Initial reservoir pressure.

b. BHFP as function of time

c. Gas and water production rate as functions of time.

d. PVT data (Black oil PVT model)

\section{Model validation}

The model was validated with several simulated cases at variable conditions of rate and pressure. The simulated cases are an output of commercial material balance equation (MBE) software and commercial numerical reservoir simulation (NRS) software. The following paragraphs will present the analysis of production data for two gas wells producing both gas and water. The validation cases were designed to reveal the capabilities of this paper approach over the available DCA approaches.

Validation Case 1: Well (1): Well (1) is producing from a gas reservoir with a moderate permeability of $20 \mathrm{mD}$, reservoir net pay

\begin{tabular}{|c|c|}
\hline Reservoir Parameters & Values \\
\hline Reservoir Formation Compressibility (Cf), psi-1 & $3.50 \mathrm{E}-06$ \\
\hline Initial Reservoir Pressure, psia & 11515 \\
\hline Reservoir Porosity, fraction & 0.2 \\
\hline Initial Gas in Place (IGIP), SCF & $7.30 \mathrm{E}+11$ \\
\hline
\end{tabular}

Table 1: Validation Case 1 - Reservoir parameters of MBE.

\begin{tabular}{|c|c|}
\hline Aquifer Parameters & Values \\
\hline Aquifer Model & $\begin{array}{c}\text { Hurst-Van Everdingen-Modified, } \\
\text { Radial Aquifer }\end{array}$ \\
\hline Aquifer Thickness, $\mathrm{ft}$ & 100 \\
\hline Aquifer Permeability, $\mathrm{mD}$ & 11 \\
\hline Aquifer Radius, $\mathrm{ft}$ & 12737 \\
\hline Aquifer Formation Compressibility (Cf), psi-1 & $3.50 \mathrm{E}-06$ \\
\hline Aquifer Water Compressibility (Cw), psi-1 & $3.00 \mathrm{E}-06$ \\
\hline Aquifer Porosity, fraction & 0.2 \\
\hline Fractional Encroachment Angle (f), (Angle/360) & 0.91 \\
\hline
\end{tabular}

Table 2: Validation Case 1 - Aquifer parameters of MBE. thickness of $100 \mathrm{ft}$, a specific gravity of 0.59 , and initial reservoir pressure of 11,515 psia.

Tables 1 and 2 show the reservoir and aquifer parameters that were used in a commercial material balance software to generate production and pressure data. We have a total of 12 years of simulated production data from the material balance program. This data have been divided into two parts. The first five years of production were used for historymatching and the last seven years of production were used to validate our prediction.

The model was used with 13 water influx aquifer models and the results obtained with each model were compared to the results obtained from material balance program.

Table 3 shows the history-matching results summary of the estimated IGIP, skin factor, error in reservoir pressure match, error in gas rate match, and error in water rate match compared to the results of the material balance program. The results show that the IGIP error is less than $10 \%$ for all the aquifer models except for Schilthuis Steady State, Hurst Modified Steady State Model, and The Van Everdingen-Hurst Model (Infinite Aquifer) where the IGIP error is greater than $10 \%$.

The error of reservoir pressure, gas saturation, and gas production rate is less than $1.5 \%$ for all the aquifer models. The error of water production rate is less than $20 \%$ for 6 aquifer models and less than $30 \%$ for two more aquifer models while it is greater than $40 \%$ for the rest of the aquifer models. The model was run in a prediction mode under a certain BHFP scenario. The prediction run shows that some aquifer models give a reasonably good prediction match while others do not. The prediction results were compared to the material balance program prediction results. Table 4 shows the error in the predicted reservoir pressure, gas production rate, water production rate, and gas saturation.

The reservoir pressure error is less than $2 \%$ for all aquifer models, the gas rate error is less than $10 \%$ for all aquifer models, and the gas saturation error is less than $6 \%$ for all aquifer models. The water rate error is less than $10 \%$ for eight aquifer models and greater than $10 \%$ for the rest of the aquifer models.

For the sake of space; the graphical results are given for only one aquifer model which show the quality of the model in both historymatch and prediction modes. Figure 2 through 6 shows a comparison between the results obtained using the developed ADCA model against the results of the classical material balance equation (MBE).

Validation Case 2: Well (2): Well (2) is producing from a gas reservoir with a good permeability of $200 \mathrm{mD}$, reservoir net pay

\begin{tabular}{|c|c|c|c|c|c|c|c|}
\hline Aquifer Model Used & IGIP (scf) & IGIP Error & Skin Factor & Pr Error & Sg Error & Gas Rate Error & Water Rate Error \\
\hline Fetkovich Radial (finite, Constant P) & $6.81 E+11$ & $7 \%$ & 29.95 & $0.05 \%$ & $0.01 \%$ & $0.10 \%$ & $22 \%$ \\
\hline Fetkovich Radial (finite, No flow) & $6.81 E+11$ & $7 \%$ & 30.64 & $0.07 \%$ & $0.00 \%$ & $0.10 \%$ & $6 \%$ \\
\hline Fetkovich Radial (infinite) & $6.81 E+11$ & $7 \%$ & 32.07 & $0.12 \%$ & $0.01 \%$ & $0.20 \%$ & $19 \%$ \\
\hline Pot Aquifer & $6.82 \mathrm{E}+11$ & $6 \%$ & 30.23 & $0.05 \%$ & $0.00 \%$ & $0.20 \%$ & $3 \%$ \\
\hline Schilthuis Steady State & $4.52 E+11$ & $38 \%$ & 19.25 & $0.37 \%$ & $0.02 \%$ & $0.70 \%$ & $25 \%$ \\
\hline Carter-Tracy & $6.81 E+11$ & $7 \%$ & 28.37 & $0.01 \%$ & $0.04 \%$ & $0.20 \%$ & $45 \%$ \\
\hline Fetkovich Linear (finite, Constant P) & $6.81 E+11$ & $7 \%$ & 31.27 & $0.08 \%$ & $0.03 \%$ & $0.20 \%$ & $41 \%$ \\
\hline Fetkovich Linear (finite, No flow) & $6.81 E+11$ & $7 \%$ & 32.24 & $0.12 \%$ & $0.01 \%$ & $0.20 \%$ & $16 \%$ \\
\hline Fetkovich Linear (infinite) & $6.81 E+11$ & $7 \%$ & 30.32 & $0.05 \%$ & $0.05 \%$ & $0.10 \%$ & $55 \%$ \\
\hline Hurst Modified Steady State Model & $4.53 E+11$ & $38 \%$ & 21.63 & $0.18 \%$ & $0.04 \%$ & $0.10 \%$ & $51 \%$ \\
\hline The Van Everdingen-Hurst Model (Finite Aquifer) & $6.82 E+11$ & $6 \%$ & 29.63 & $0.03 \%$ & $0.00 \%$ & $0.10 \%$ & $4 \%$ \\
\hline The Van Everdingen-Hurst Model (Infinite Aquifer) & $1.36 \mathrm{E}+12$ & $87 \%$ & 35.07 & $0.40 \%$ & $0.15 \%$ & $1.10 \%$ & $88 \%$ \\
\hline Fetkovich Model (Bottom Drive) & $6.81 E+11$ & $7 \%$ & 32.15 & $0.12 \%$ & $0.00 \%$ & $0.20 \%$ & $9 \%$ \\
\hline
\end{tabular}

Table 3: Validation Case 1 - History matching results summary for validation case (1). 
Citation: Abdelkhalek MS, El-Banbi AH, Sayyouh MH (2017) Analytical Decline Curve Analysis Model for Water Drive Gas Reservoirs. J Pet Environ Biotechnol 8: 343. doi: 10.4172/2157-7463.1000343

Page 5 of 9

thickness of $150 \mathrm{ft}$, a specific gravity of 0.79 , and initial reservoir pressure of 5,997 psia.

The reservoir and aquifer parameters used to create the simulated data in the numerical reservoir simulation (NRS) program are shown in Tables 5 and 6.

A total of 12 years of simulated production data from NRS is available. This data were used in two modes. The first seven years of production were used in history-matching mode while the last five years of production were used to test the prediction results. The model has been used with 12 water influx aquifer models and the results obtained with each model were compared to the results obtained from the numerical reservoir simulation program.

Table 7 shows the results of the history-matching mode. It gives a summary of the estimated IGIP, skin factor, error in reservoir pressure match, error in gas production rate match, and error in water production rate match compared to the results of the numerical reservoir simulation program (Figures 3-6).

The results show that the IGIP error is less than $2 \%$ for eight aquifer models and less than $20 \%$ for two aquifer models while it is greater than $20 \%$ for only two aquifer models. The error of reservoir pressure, gas saturation, and gas production rate is less than $10 \%$ for eight aquifer models. The error of water production rate is less than $10 \%$ for six aquifer models and less than $20 \%$ for two more aquifer models.

\begin{tabular}{|c|c|c|c|c|}
\hline Aquifer Model Used & Pr Error & $\begin{array}{l}\text { Gas Rate } \\
\text { Error }\end{array}$ & $\begin{array}{l}\text { Water Rate } \\
\text { Error }\end{array}$ & $\begin{array}{c}\mathrm{Sg} \\
\text { Error }\end{array}$ \\
\hline Pot Aquifer Model & $10 \%$ & $1.20 \%$ & $3 \%$ & $0.00 \%$ \\
\hline Schilthuis Steady State Model & $1.20 \%$ & $6.40 \%$ & $1117 \%$ & $2.60 \%$ \\
\hline $\begin{array}{l}\text { Hurst Modified Steady State } \\
\text { Model }\end{array}$ & $1.10 \%$ & $8.90 \%$ & $4107 \%$ & $5.20 \%$ \\
\hline $\begin{array}{l}\text { The Van Everdingen-Hurst } \\
\text { Model (Finite Aquifer) }\end{array}$ & $0.10 \%$ & $1.60 \%$ & $0 \%$ & $0.00 \%$ \\
\hline $\begin{array}{l}\text { The Van Everdingen-Hurst } \\
\text { Model (Infinite Aquifer) }\end{array}$ & $1.30 \%$ & $9.30 \%$ & $85 \%$ & $0.80 \%$ \\
\hline $\begin{array}{c}\text { The Carter-Tracy Unsteady } \\
\text { State Model }\end{array}$ & $.10 \%$ & $3.40 \%$ & $24 \%$ & $0.10 \%$ \\
\hline Fetkovich Radial (infinite) & $10 \%$ & $20 \%$ & $8 \%$ & $0.00 \%$ \\
\hline $\begin{array}{l}\text { Fetkovich Radial (finite, } \\
\text { Constant } P \text { ) }\end{array}$ & $00 \%$ & 0.50 & 2 & $0.00 \%$ \\
\hline Fetkovich Radial (finite, No flow) & $0.00 \%$ & 80 & $8 \%$ & $0.10 \%$ \\
\hline Fetkovich Linear (infinite) & $0.00 \%$ & $0.20 \%$ & $8 \%$ & $0.00 \%$ \\
\hline $\begin{array}{l}\text { Fetkovich Linear (finite, } \\
\text { Constant } P \text { ) }\end{array}$ & $0.00 \%$ & $0.30 \%$ & $3 \%$ & 0.00 \\
\hline Fetkovich Linear (finite, No flow) & 0.00 & 0.007 & 210 & $0.00 \%$ \\
\hline Fetkovich Model (Bottom Drive) & $0.00 \%$ & $0.80 \%$ & $1 \%$ & $0.00 \%$ \\
\hline
\end{tabular}

Table 4: Validation Case 1 - Prediction results summary.

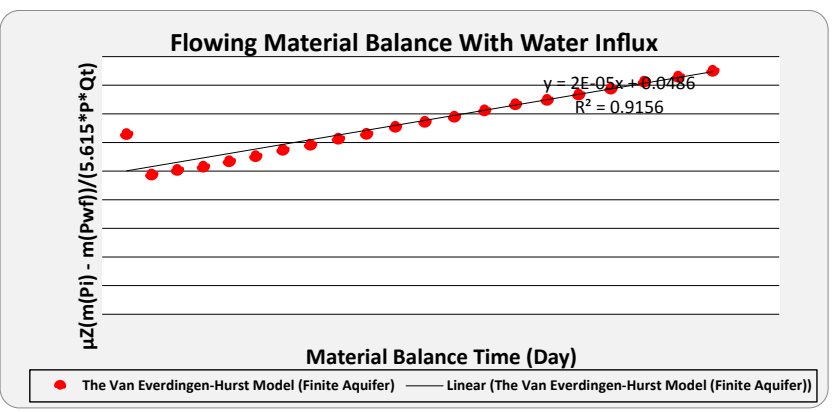

Figure 2 : Validation Case 1 - Diagnostic plot using the Van Everdingen-Hurst Finite aquifer model.

\begin{tabular}{|c|c|}
\hline Reservoir Parameters & Values \\
\hline Reservoir Permeability, mD & 200 \\
\hline Initial Reservoir Pressure, psia & 5997 \\
\hline Reservoir Porosity, fraction & 0.2 \\
\hline Initial Gas in Place (IGIP), SCF & $6.83 \mathrm{E}+11$ \\
\hline
\end{tabular}

Table 5: Validation Case 2 - Reservoir parameters for NRS.

\begin{tabular}{|c|c|}
\hline Aquifer Parameters & Values \\
\hline Aquifer Model & Numerical Aquifer \\
\hline Aquifer Permeability, $\mathrm{mD}$ & 100 \\
\hline Aquifer Length, $\mathrm{ft}$ & 10000 \\
\hline Aquifer Area & $1.00 \mathrm{E}+07$ \\
\hline Aquifer Porosity, fraction & 0.2 \\
\hline
\end{tabular}

Table 6: Validation Case 2 - Aquifer parameters for NRS.

\begin{tabular}{|c|c|c|c|c|c|c|c|}
\hline $\begin{array}{c}\text { Aquifer Model } \\
\text { Used }\end{array}$ & $\begin{array}{c}\text { IGIP } \\
\text { (scf) }\end{array}$ & $\begin{array}{c}\text { IGIP } \\
\text { Error }\end{array}$ & $\begin{array}{c}\text { Skin } \\
\text { Factor }\end{array}$ & $\begin{array}{c}\text { Pr } \\
\text { Error }\end{array}$ & $\begin{array}{c}\text { Sg } \\
\text { Error }\end{array}$ & $\begin{array}{c}\text { Gas } \\
\text { Rate } \\
\text { Error }\end{array}$ & $\begin{array}{c}\text { Water } \\
\text { Rate } \\
\text { Error }\end{array}$ \\
\hline $\begin{array}{c}\text { Fetkovich Radial } \\
\text { (finite, Constant P) }\end{array}$ & $\begin{array}{c}6.68 \mathrm{E}+ \\
11\end{array}$ & $2 \%$ & 22 & $0 \%$ & $2 \%$ & $1 \%$ & $6 \%$ \\
\hline $\begin{array}{c}\text { Fetkovich Radial } \\
\text { (finite, No flow) }\end{array}$ & $\begin{array}{c}6.69 \mathrm{E}+ \\
11\end{array}$ & $2 \%$ & 24 & $0 \%$ & $3 \%$ & $3 \%$ & $16 \%$ \\
\hline $\begin{array}{c}\text { Fetkovich Radial } \\
\text { (infinite) }\end{array}$ & $\begin{array}{c}6.69 \mathrm{E}+ \\
11\end{array}$ & $2 \%$ & 20 & $0 \%$ & $2 \%$ & $1 \%$ & $6 \%$ \\
\hline $\begin{array}{c}\text { Pot Aquifer } \\
\text { Schilthuis Steady }\end{array}$ & $\begin{array}{c}1.13 \mathrm{E}+ \\
\text { State }\end{array}$ & $66 \%$ & 38 & $0 \%$ & $5 \%$ & $1 \%$ & $16 \%$ \\
\hline $\begin{array}{c}12 \\
\text { Carter-Tracy }\end{array}$ & $\begin{array}{c}5.57 \mathrm{E}+ \\
11\end{array}$ & $18 \%$ & 13 & $0 \%$ & $0 \%$ & $70 \%$ & $41 \%$ \\
\hline $\begin{array}{c}\text { Fetkovich Linear } \\
\text { (finite, Constant P) }\end{array}$ & $\begin{array}{c}6.68 \mathrm{E}+ \\
11\end{array}$ & $2 \%$ & 24 & $0 \%$ & $2 \%$ & $0 \%$ & $2 \%$ \\
\hline $\begin{array}{c}\text { Fetkovich Linear } \\
\text { (finite, No flow) }\end{array}$ & $\begin{array}{c}6.70 \mathrm{E}+ \\
11\end{array}$ & $2 \%$ & 26 & $0 \%$ & $4 \%$ & $3 \%$ & $0 \%$ \\
\hline $\begin{array}{c}\text { Fetkovich Linear } \\
\text { (infinite) }\end{array}$ & $\begin{array}{c}6.66 \mathrm{E}+ \\
11\end{array}$ & $2 \%$ & 3 & $1 \%$ & $0 \%$ & $69 \%$ & $28 \%$ \\
\hline $\begin{array}{c}\text { The Van } \\
\text { Everdingen-Hurst } \\
\text { Model (Finite } \\
\text { Aquifer) }\end{array}$ & $\begin{array}{c}6.80 \mathrm{E}+ \\
11\end{array}$ & $0.30 \%$ & 41 & $0 \%$ & $11 \%$ & $2 \%$ & $3 \%$ \\
\hline $\begin{array}{c}\text { The Van } \\
\text { Everdingen-Hurst } \\
\text { Model (Infinite } \\
\text { Aquifer) }\end{array}$ & $\begin{array}{c}1.14 \mathrm{E}+ \\
12\end{array}$ & $66 \%$ & 44 & $0 \%$ & $3 \%$ & $12 \%$ & $100 \%$ \\
\hline $\begin{array}{c}\text { Fetkovich Model } \\
\text { (Bottom Drive) }\end{array}$ & $\begin{array}{c}6.76 \mathrm{E}+ \\
11\end{array}$ & $1 \%$ & 36 & $0 \%$ & $8 \%$ & $1 \%$ & $8 \%$ \\
\hline
\end{tabular}

Table 7: Validation Case 2 - History matching results summary.

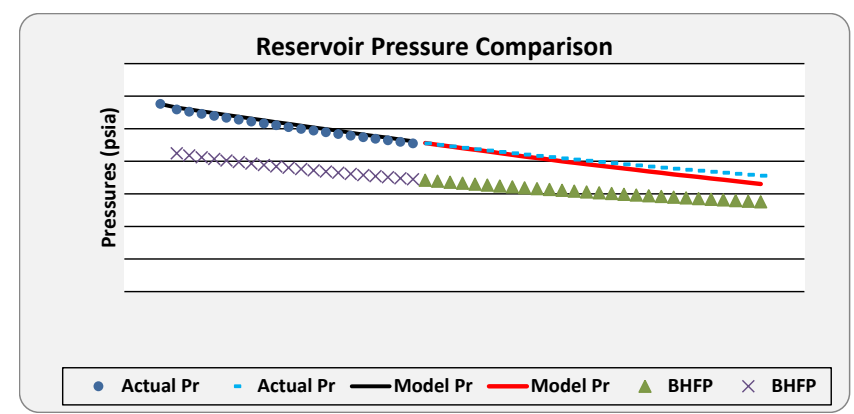

Figure 3: Validation Case 1 - Reservoir pressure match using the Van Everdingen-Hurst Finite aquifer model.

The model has been run in a prediction mode with a specific BHFP scenario. In the prediction run; some aquifer models still hold a reasonably good prediction match while others have less good results. 
Citation: Abdelkhalek MS, El-Banbi AH, Sayyouh MH (2017) Analytical Decline Curve Analysis Model for Water Drive Gas Reservoirs. J Pet Environ Biotechnol 8: 343. doi: 10.4172/2157-7463.1000343

Page 6 of 9

The prediction results have been compared to the numerical reservoir simulation prediction results. Table 8 shows the error in the predicted reservoir pressure, gas production rate, water production rate, and gas saturation

\section{Field cases}

The developed ADCA model was used to calculate reserves and predict the performance of gas reservoirs producing under water-drive mechanism. In the following section, two field cases are presented. The field cases show the capability of the model to be used with real field cases.

Field case 1: Well (1B): Well (1B) is producing from an offshore sandstone reservoir with high permeability. Average permeability is estimated from core data to be in the order of $286 \mathrm{mD}$, reservoir net pay thickness is $85 \mathrm{ft}$, gas with specific gravity of 0.54 , and initial reservoir pressure of 3,371 psia.

Well (1B) started production in June 2013 with an initial gas production rate of $70 \mathrm{MMscfd}$ and with no water production. The well

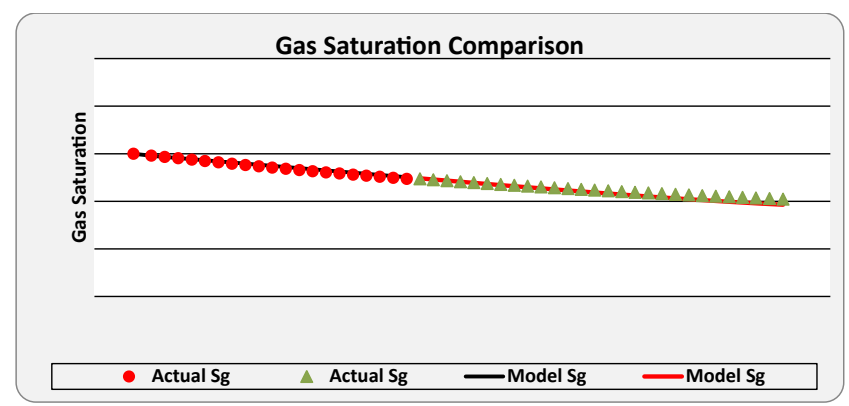

Figure 4: Validation Case 1 - Gas saturation match using the Van EverdingenHurst finite aquifer model.

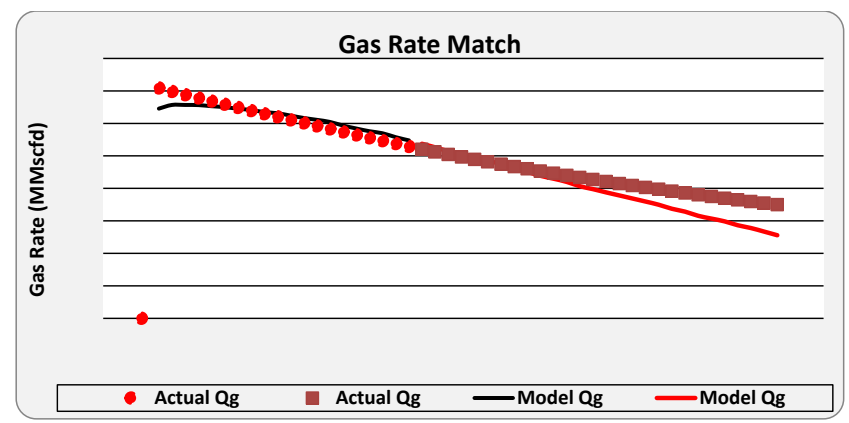

Figure 5: Validation Case 1 - Gas rate match using the Van Everdingen-Hurst finite aquifer model.

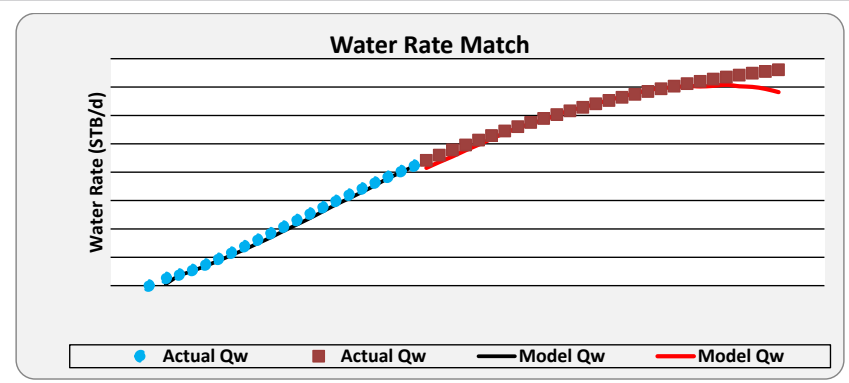

Figure 6: Validation Case 1 - Water rate match using the Van EverdingenHurst finite aquifer model.

\begin{tabular}{|c|c|c|c|c|}
\hline Aquifer Model Used & Pr Error & $\begin{array}{l}\text { Gas } \\
\text { Rate } \\
\text { Error }\end{array}$ & $\begin{array}{c}\text { Water } \\
\text { Rate } \\
\text { Error }\end{array}$ & Sg Error \\
\hline Pot Aquifer Model & $0 \%$ & $2 \%$ & $62 \%$ & $32 \%$ \\
\hline $\begin{array}{l}\text { The Van Everdingen-Hurst Model (Finite } \\
\text { Aquifer) }\end{array}$ & $0 \%$ & $510 \%$ & $6566 \%$ & $37 \%$ \\
\hline The Carter-Tracy Unsteady State Model & $5 \%$ & $289 \%$ & $8403 \%$ & $44 \%$ \\
\hline Fetkovich Radial (infinite) & $0 \%$ & $3 \%$ & $33 \%$ & $16 \%$ \\
\hline Fetkovich Radial (finite, Constant P) & $0 \%$ & $9 \%$ & $1 \%$ & $13 \%$ \\
\hline Fetkovich Radial (finite, No flow) & $0 \%$ & $25 \%$ & $9 \%$ & $13 \%$ \\
\hline Fetkovich Linear (infinite) & $0 \%$ & $11 \%$ & $147 \%$ & $8 \%$ \\
\hline Fetkovich Linear (finite, Constant P) & $0 \%$ & $7 \%$ & $11 \%$ & $15 \%$ \\
\hline Fetkovich Linear (finite, No flow) & $0 \%$ & $28 \%$ & $16 \%$ & $15 \%$ \\
\hline Fetkovich Model (Bottom Drive) & $0 \%$ & $6 \%$ & $40 \%$ & $27 \%$ \\
\hline
\end{tabular}

Table 8: Validation Case 2 - Prediction results summary.

\begin{tabular}{|c|c|c|c|c|}
\hline Aquifer Model Used & IGIP (scf) & $\begin{array}{l}\text { Pr Error } \\
(\%)\end{array}$ & $\begin{array}{l}\text { Gas Rate } \\
\text { Error (\%) }\end{array}$ & $\begin{array}{c}\text { Water Rate } \\
\text { Error (\%) }\end{array}$ \\
\hline $\begin{array}{l}\text { Fetkovich Radial (finite, } \\
\text { Constant P) }\end{array}$ & $8.71 E+10$ & $3 \%$ & $3 \%$ & $3 \%$ \\
\hline $\begin{array}{l}\text { Fetkovich Radial (finite, No } \\
\text { flow) }\end{array}$ & $1.06 \mathrm{E}+11$ & $1 \%$ & $2 \%$ & $2 \%$ \\
\hline Fetkovich Radial (infinite) & $9.92 E+10$ & $1 \%$ & $6 \%$ & $6 \%$ \\
\hline Pot Aquifer & $1.03 E+11$ & $0 \%$ & $3 \%$ & $3 \%$ \\
\hline Schilthuis Steady State & $1.03 E+11$ & $9 \%$ & $5 \%$ & $11 \%$ \\
\hline Carter-Tracy & $1.00 \mathrm{E}+11$ & $4 \%$ & $6 \%$ & $6 \%$ \\
\hline $\begin{array}{l}\text { Fetkovich Linear (finite, } \\
\text { Constant } P \text { ) }\end{array}$ & $9.22 \mathrm{E}+10$ & $3 \%$ & $2 \%$ & $2 \%$ \\
\hline $\begin{array}{l}\text { Fetkovich Linear (finite, No } \\
\text { flow) }\end{array}$ & $1.12 E+11$ & $3 \%$ & $2 \%$ & $3 \%$ \\
\hline Fetkovich Linear (infinite) & $1.09 \mathrm{E}+11$ & $1 \%$ & $4 \%$ & $6 \%$ \\
\hline $\begin{array}{l}\text { The Van Everdingen-Hurst } \\
\text { Model (Finite Aquifer) }\end{array}$ & $1.03 E+11$ & $1 \%$ & $3 \%$ & $3 \%$ \\
\hline $\begin{array}{c}\text { Fetkovich Model (Bottom } \\
\text { Drive) }\end{array}$ & $9.48 \mathrm{E}+10$ & $0 \%$ & $4 \%$ & $3 \%$ \\
\hline
\end{tabular}

Table 9: Field Case 1 - Summary of the history-match results.

was producing water-free gas until August 2015 when water started to break through and gas production started to take a sharp decline. Well (1B) has a permanent down-hole gauge (PDHG). Therefore, the well has continuous BHFP measurements along with gas and water production rates. We subjected the production data to quality control and quality assurance (QA and QC) procedures before performing our analysis $[17,18]$. stages:

The QA and QC of production data has to pass through three

a. Outlier removal.

b. Consistency between rate and pressure.

c. Liquid loading in the wellbore.

The first step in production data QA is the removal of outliers. If the outlier data have not been identified and removed, it can give misleading interpretation and results. The second step is to make sure that there is a consistency between pressure and rate data. If the rate and pressure data are inconsistent with each other, we should not use these data for analysis.

The last step in production data QA is to make sure we do not have any liquid loading in the well-bore. We have used Turner liquid loading model to investigate the production data for the field cases. Any data falling below the Turner critical rate have been identified and excluded from the analytical model $[19,20]$. The production data QA 
Citation: Abdelkhalek MS, El-Banbi AH, Sayyouh MH (2017) Analytical Decline Curve Analysis Model for Water Drive Gas Reservoirs. J Pet Environ Biotechnol 8: 343. doi: 10.4172/2157-7463.1000343

Page 7 of 9

and QC for well (1B) shows no issues and the whole production range can be used for analysis.

The model was used with 11 different water influx aquifer models and the results obtained with each aquifer model were compared to the actual field data. Production data for this field case was used to run the ADCA model in a history-match mode. Table 9 shows a summary of the estimated IGIP, skin factor, and error in reservoir pressure match, error in gas production rate match, and error in water production rate match compared to the actual field data.

The error of reservoir pressure, gas production rate and water production rate is less than $11 \%$ for all the aquifer models. Figure 7

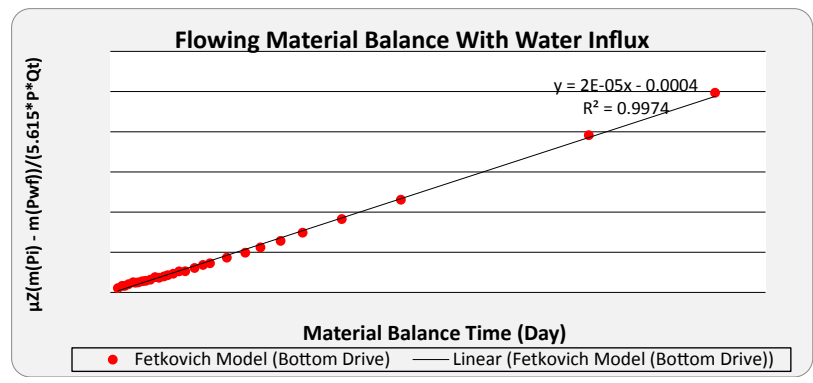

Figure 7: Field Case 1 - Diagnostic plot using Van Everdingen-Hurst finite aquifer.

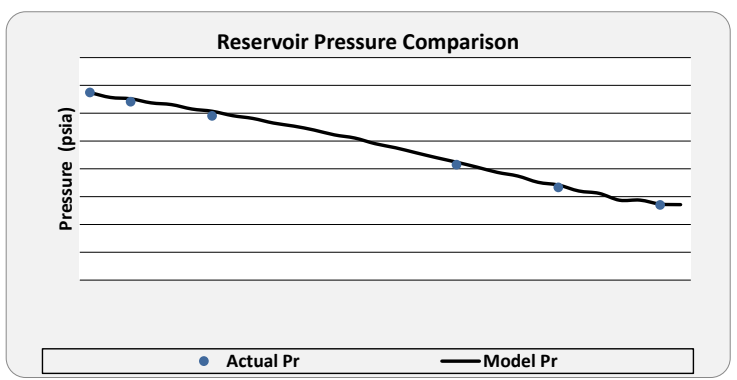

Figure 8: Field Case 2 - Reservoir pressure match using Fetkovich bottom drive aquifer.

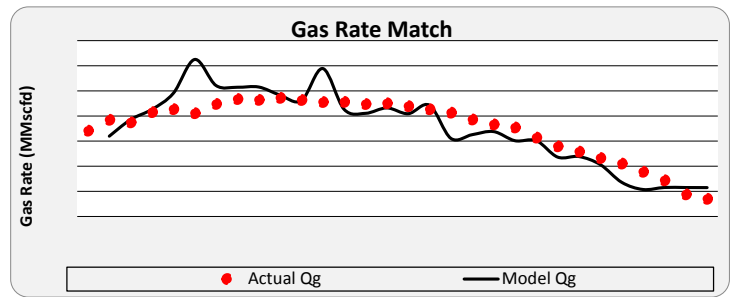

Figure 9: Field Case 2 - Gas rate match using Fetkovich bottom drive aquifer.

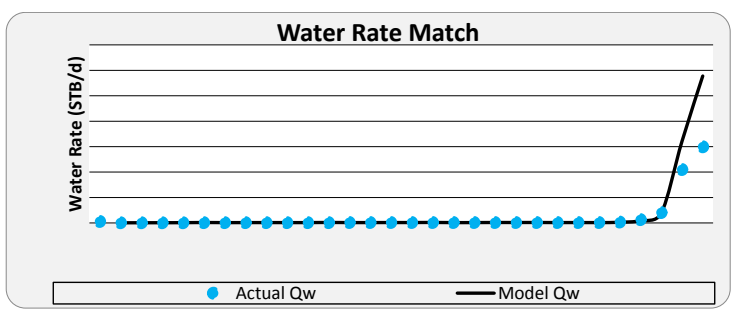

Figure 10: Field Case 2 - Water rate match using Fetkovich bottom drive aquifer.

\begin{tabular}{|c|c|c|c|c|}
\hline Aquifer Model Used & IGIP (scf) & $\begin{array}{l}\text { Pr Error } \\
(\%)\end{array}$ & $\begin{array}{l}\text { Gas Rate } \\
\text { Error (\%) }\end{array}$ & $\begin{array}{l}\text { Water Rate } \\
\text { Error (\%) }\end{array}$ \\
\hline $\begin{array}{l}\text { Fetkovich Radial (finite, } \\
\text { Constant } P \text { ) }\end{array}$ & $1.62 E+11$ & $0.43 \%$ & $7 \%$ & $3 \%$ \\
\hline $\begin{array}{l}\text { Fetkovich Radial (finite, No } \\
\text { flow) }\end{array}$ & $1.62 \mathrm{E}+11$ & $0.78 \%$ & $7 \%$ & $2 \%$ \\
\hline Fetkovich Radial (infinite) & $1.62 \mathrm{E}+11$ & $0.41 \%$ & $11 \%$ & $8 \%$ \\
\hline Pot Aquifer & $1.63 E+11$ & $0.46 \%$ & $7 \%$ & $9 \%$ \\
\hline $\begin{array}{l}\text { Fetkovich Linear (finite, } \\
\text { Constant } P \text { ) }\end{array}$ & $1.61 E+11$ & $0.09 \%$ & $30 \%$ & $71 \%$ \\
\hline $\begin{array}{l}\text { Fetkovich Linear (finite, No } \\
\text { flow) }\end{array}$ & $1.62 E+11$ & $0.26 \%$ & $39 \%$ & $22 \%$ \\
\hline Fetkovich Linear (infinite) & $1.61 \mathrm{E}+11$ & $0.10 \%$ & $29 \%$ & $24 \%$ \\
\hline $\begin{array}{l}\text { The Van Everdingen-Hurst } \\
\text { Model (Finite Aquifer) }\end{array}$ & $1.63 E+11$ & $0.46 \%$ & $7 \%$ & $4 \%$ \\
\hline $\begin{array}{l}\text { Fetkovich Model (Bottom } \\
\text { Drive) }\end{array}$ & $1.62 E+11$ & $0.44 \%$ & $8 \%$ & $4 \%$ \\
\hline
\end{tabular}

Table 10: Field Case 2 - Summary of the history match results.

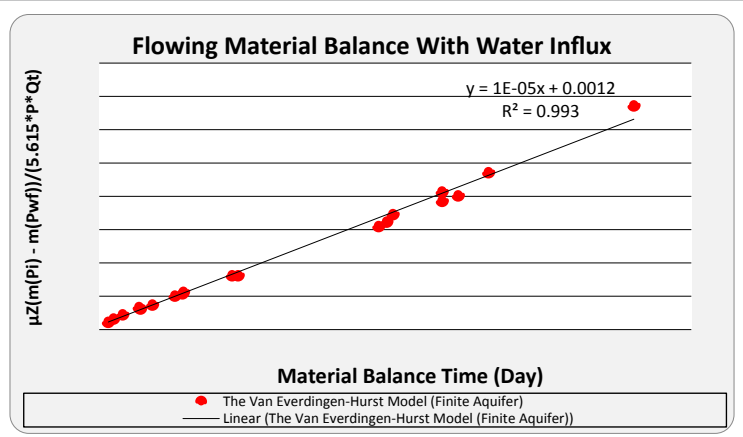

Figure 11: Field Case 2 - Diagnostic plot using Van Everdingen-Hurst finite aquifer.

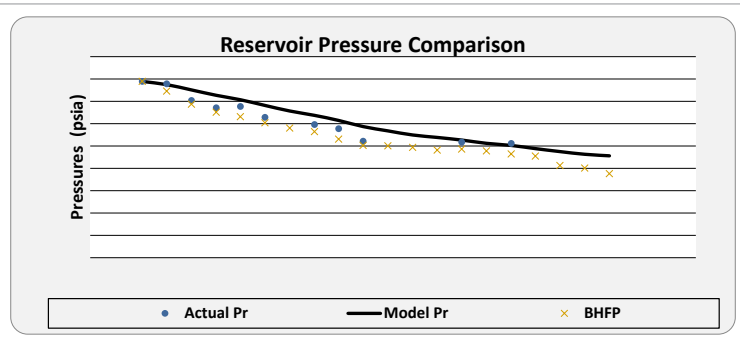

Figure 12: Field Case 2 - Reservoir pressure match using Van EverdingenHurst finite aquifer.

through 10 show the match for reservoir pressure, gas production rate, and water production rate.

Field case 2: Well (1D): Well (1D) is producing from another gas reservoir with average permeability of $110 \mathrm{mD}$, reservoir net pay thickness of $279 \mathrm{ft}$, gas specific gravity of 0.57 , and initial reservoir pressure of 3,945 psia (Figures 8-10).

Well (1D) started production in July 2005 with an initial gas production rate of $108 \mathrm{MMscfd}$ and with no water production. The well was producing water-free gas until October 2007 when water production started and gas production started to decline. A permanent down-hole gauge (PDHG) was installed in well (1D) and the well has continuous BHFP measurements along with gas and water production rates.

QA and QC of the production data was performed and revealed that the production data had no issues.

Similar to the above field case, the ADCA model was used with 


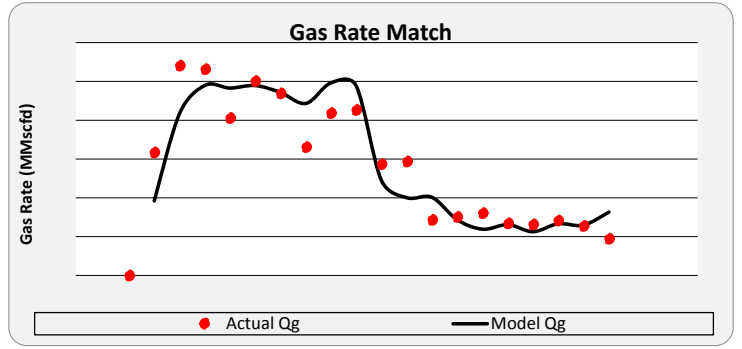

Figure 13: Field Case 2 - Gas rate match using Van Everdingen-Hurst finite aquifer.

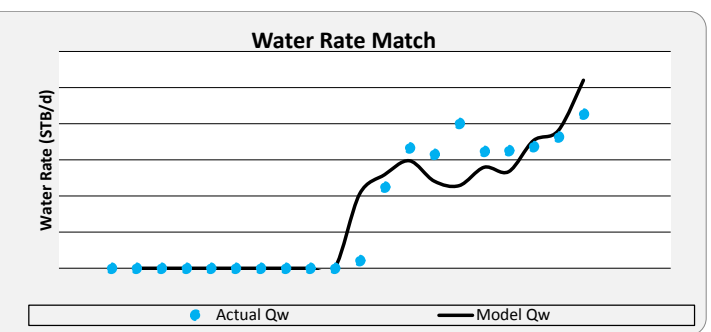

Figure 14: Field Case 2 - Water rate match using Van Everdingen-Hurst finite aquifer.

nine different water influx aquifer models and the results obtained with each model. The model was run in a history-match mode only for the entire production history of five years.

Table 10 shows a summary of the history-match results in terms of estimated IGIP, error in reservoir pressure match, error in gas production rate match, and error in water production rate match. Figure 11 through 14 show the diagnostic plot for the developed analytical decline curve analysis model and the match of the different parameters attained from the model. The calculated IGIP from Figure 11 is 163 Bscf. This IGIP was estimated from the slope of the straight line of the model diagnostic plot in Figure 10.

The reservoir pressure match is shown in Figure 12. The average match error is less than $0.5 \%$. There is a good agreement between the model gas production rate and the actual gas production rate as shown in Figure 13. The average error of gas rate match is $7 \%$.

The water production rate match is also of a good quality as shown in Figure 14. The model was able to match the water breakthrough time and the water production trend. The average error of water production rate match is $4 \%$.

\section{Conclusion}

The following conclusions can be drawn from the above cases:

1. A simple model was developed to estimate the IGIP, reservoir pressure, gas saturation, gas production rate, and water production rate for gas wells producing from water drive gas reservoirs. The model requires minimum input data (production history of both gas and water, estimates of bottom-hole flowing pressure, and PVT data).

2. The developed model is based on extending the flowing material balance concept to account for water influx effect.

3. The model couple's material balance for gas reservoirs, IPR or flow equation model, and aquifer models. The model works in both history-match and prediction modes.
4. The model has been validated against material balance commercial program and commercial simulator. For the validation cases, the model gave errors as low as $2 \%$ for IGIP estimate, $1 \%$ for reservoir pressure estimate, and $2 \%$ for gas and water production rates.

5. The model has the capability to be run in a prediction mode at variable bottom-hole flowing pressure, hence the ability to test different production scenarios.

6. Testing this model using a large number of commonly used aquifer models shows that best-fit aquifer model may not be unique. However, the prediction under different aquifer models will converge if there is enough historical data.

7. The model was also used with real production data from 2 wells producing from gas reservoir under water-drive.

\section{References}

1. Tarek A (2001) Reservoir Engineering Hand Book, (2nd edn). Gulf Professional Publishing Co. Butterworth-Heinemann, Oxford, UK.

2. Dake LP (1998) Fundamentals of Reservoir Engineering, (17th edn). Elsevier Science B.V., The Hague, The Netherlands.

3. Craft BC, Hawkins M (1991) Applied Petroleum Reservoir Engineering, (2nd edn). Prentice Hall PRT, Englewood Cliffs-New Jersey, USA.

4. Mattax CC, Dalton RL (1990) Reservoir Simulation, SPE Monograph Volume 13, Society of Petroleum Engineers Inc., Richardson-Texas.

5. Ertekin T, Abou-Kassem JH, King GR (2001) Basic Applied Reservoir Simulation, (1st edn)., Richardson-Texas, Society of Petroleum Engineers Inc.

6. Houze O, Viturat D, Fjaere OS (2012) Dynamic data analysis, (4th ed). Kappa Sophia Antipolis.

7. Arps JJ (1945) Analysis of decline curve. SPE Journal: 228-247. SPE945228-G.

8. Fetkovich MJ (1980) Decline curve analysis using type curves. SPE Journal: 1065-1077. 4629-PA

9. Blasingame TA, Palacio JC (1993) Decline-curve analysis with type curves - Analysis of gas well production data. Paper SPE 25909 presented at SPE Joint Rocky Mountain Regional and Low Permeability Reservoirs Symposium, Denver, Colorado.

10. Blasingame TA, Doublet LE, McCollum TJ (1994) Decline curve analysis using type cures-analysis of oil well production data using material balance time: Application to field Cases). Paper SPE 28688, Petroleum Conference and Exhibition, Veracruz, Mexico.

11. Blasingame TA, Johnston JL, Lee WJ (19889) Type-curve analysis using the pressure integral method. Paper SPE 18799 presented at the SPE California Regional Meeting, Bakersfield, California.

12. Agarwal RG, Gardner CD, Kleinstebier SW (1998) Analyzing well production data using combined type curve and decline curve analysis concepts. Paper SPE 49222 presented at the SPE Annual Technical Conference and Exhibition, New Orleans, Louisiana.

13. Mattar L, Anderson Z (2005) Dynamic material balance (Oil or Gas in place without shut ins)," Paper presented at the Petroleum Society's 6th Canadian International Petroleum Conference, $56^{\text {th }}$ Annual Technical Meeting, Alberta, Canada.

14. Mattar L, McNeil R (1995) The "flowing" material balance procedure. Paper presented at the Petroleum Society's Canadian International Petroleum Conference, 46th Annual Technical Meeting, Alberta, Canada.

15. Mohammed S, Enty GS (2013) Analysis of gas production data using flowing material balance method. Paper presented at the Nigeria Annual International Conference and Exhibition, Lagos, Nigeria.

16. Guzman JD, Arevalo JA, Espinola O (2014) Reserves evaluation of dry gas reservoirs through flowing pressure material balance methods. Paper presented at the SPE Biennial Energy Resources Conference, Port of Spain, Trinidad.

17. Mattar L, Nobakht M (2009) Diagnostics of data quality for analysis of production data. Paper presented at the Canadian International Petroleum Conference, Alberta, Canada. 
Citation: Abdelkhalek MS, El-Banbi AH, Sayyouh MH (2017) Analytical Decline Curve Analysis Model for Water Drive Gas Reservoirs. J Pet Environ Biotechnol 8: 343. doi: 10.4172/2157-7463.1000343

Page 9 of 9

18. Mattar L, Rushing JA, Anderson DM (2006) Production data analysis Challenges, pitfalls, diagnostics. Paper SPE 102048 presented at the 2006 SPE Annual Technical Conference and Exhibition, San Antonio, Texas.

19. Turner RG, Hubbard MG, Dukler AE (1969) Analysis and prediction of minimum flow rate for the continuous removal of liquids from gas wells. SPE Journal: 1475-1482. SPE- 2198-PA.

20. Beggs HD (1984) Gas production operations, (1st edn). OGCI Publications, Tulsa. 